\title{
Determinants of Income Smoothing: Empirical Evidence from Indonesian Stock Exchange
}

\author{
Putu Wenny Saitri ${ }^{1}$, and I Gede Cahyadi Putra ${ }^{2}$ \\ \{wenny.saitri@gmail.com ${ }^{1}$,gdcahyadi@unmas.ac.id ${ }^{2}$ \} \\ Economy Faculty of Mahasaraswati Denpasar University, Bali, Indonesia ${ }^{1,2}$
}

\begin{abstract}
This study aims to analyze the effect of Managerial Ownership, Company Size, Profitability, Leverage and Tax on Income Smoothing. The population of the study are manufacturing companies listed on the Indonesia Stock Exchange in 2015-2017. The data analysis technique used in this study is logistic regression. The sampling technique used was purposive sampling and the number of samples from this study were 20 manufacturing companies. The results of this study indicate that the leverage variable has a positive effect on income smoothing, while the managerial ownership, firm size, profitability and tax have no effect on income smoothing.
\end{abstract}

Keywords: Managerial Ownership, Company Size, Profitability, Leverage, Taxes, Income Smoothing.

\section{Introduction}

Financial statements are one of the tools used to assess the performance of a company. The parties interested in the company use financial statements as a basis for decision making because financial statements contain information about management's performance, one of which is reflected in the company's earnings information. Income smoothing is a method used by company management in influencing financial statements by slowing down or accelerating the recognition of income or expenses in order to deceive users of financial statements who want to know the position and performance of the company. Shareholder satisfaction increases with the existence of stable earnings growth (Saputra, 2014). This action is carried out to increase the value and performance of the company so that it looks good to influence investors in making decisions to invest their capital.

As for several factors that encourage companies to practice income smoothing, including managerial ownership, company size, profitability, leverage and tax. Managerial ownership by the management of the company will cause management to easily manage the company's financial statements, because management has more information about the company and management will do income smoothing to stabilize the profits generated by the company. Research on the influence of managerial ownership on income smoothing practices conducted by Noviana and Yuyetta (2011) found that managerial ownership did not have a significant effect on income smoothing. This is contrary to the research conducted by Widiawati (2016) who found the results that managerial ownership has a significant positive effect on income smoothing.

Large size of the company shows that the company has developed so that investors will respond positively and the value of the company will increase. Research on the effect of company size on income smoothing practices conducted by Budiasih (2009) found results that firm size had a significant positive effect on income smoothing. This is contrary to the research conducted by Juniarti and Corolina (2005) which found that the size of the company had no significant effect on income smoothing.

Companies that have high profitability tend to do income smoothing because management knows the company's ability to earn profits in the future. Research conducted by Agustianto (2014), Saputra (2014), and Budiasih (2009) found that profitability had a positive effect on income smoothing practices. Another result was found by Setyaningtyas (2014) who found that profitability did not affect the income smoothing practice.

Leverage owned by a company based on the debt covenant hypothesis in positive accounting theory stated that companies with a high level of debt tend to manage profits to avoid violations of debt agreements (Rahmawati, 2012). In the research conducted by Dewi (2010) who found results that financial leverage had a significant effect on income smoothing practices. This is contrary to the research 
conducted by Widaryanti (2009), Rahmawati (2012), and Budiasih (2009) who found that leverage did not significantly influence the practice of income smoothing.

Management's desire to always pay low taxes is one of the factors that encourages management to practice income smoothing. Profit that is too high will result in a large tax rate that must be paid by the company, whereas low profits will show the poor performance of the company. The research conducted by Pratiwi and Handayani (2014) found that the tax did not affect the income smoothing practice. Another result was found by Widiawati (2016) who found that tax had a significant positive effect on income smoothing practices.

Based on the results of previous inconsistent research, researchers are interested in analyzing the factors that influence income smoothing in manufacturing companies listed on the Indonesia Stock Exchange in the period 2015-2017. So that this research is expected to expand the results of previous studies.

\section{Literature Review}

\subsection{Agency Theory}

Income smoothing in a company can be explained through the agency theory approach. Agency relationship is defined by Jensen and Meckling (1976) in Wahyuningsih (2007) as a contract between one person or more owners (principals) who hire another person (agent) to do several services on behalf of the owner which includes delegating decision-making authority to the agent. Even though there is a contract, the agent will not do the best for the benefit of the owner. This is because agents also have an interest in maximizing their welfare. In other words, the agent will take a policy that benefits him before providing benefits to the owner of the company.

\subsection{Positive Accounting Theory}

Watts and Zimmerman (1978) in Agustianto (2014) formulated an understanding of income smoothing formulated in Positive Accounting Theory (PAT), namely the assumption that the purpose of accounting theory is to explain accounting practices, including:

a) The Bonus Plan Hypothesis

This hypothesis assumes that companies that use bonus plans will tend to use accounting methods that can increase reported earnings in the current period from future profits. This is done to maximize the bonus they will get because how much the level of profit generated is often used as the basis for measuring the success of performance

b) Debt Convenant Hypothesis

This hypothesis is related to the terms and agreements that must be fulfilled by the company in a debt covenant. Some debt agreements have conditions that must be met by the borrower during the agreement period, if such an agreement is betrayed, the debt agreement can provide or issue a penalty.

c) The Political Cost Hypothesis

This hypothesis states that the greater the political costs faced by the company, the greater the tendency of companies to use accounting choices that can reduce profits, because companies that have a high level of profit are considered to receive broad attention from consumers and the media who will also be interesting the attention of the government and regulators to cause political costs, including government intervention, higher taxation, and various other demands that could increase political costs.

\subsection{Income Smoothing}

Management actions to make income smoothing are generally based on various reasons including to satisfy the interests of the owner of the company such as increasing the value of the company so that the assumption arises that the company concerned has a low risk of uncertainty. Income smoothing is one pattern of earnings management where management seeks to stabilize (flatten) corporate profits for several periods with specific objectives (Wulandari, 2013). Profit actions are deliberately carried out by management within the limits of existing rules and lead to a desired level of reported profits. The parties interested in the company tend to avoid high risks so that they are more interested in companies with stable profits compared to fluctuating profits. 


\subsection{Hypotheses}

Managerial ownership by the management of the company will cause management to easily manage the company's financial statements, because management has more information about the company. Management will do income smoothing to stabilize the profits generated by the company. Christiawan and Tarigan (2004) state that managerial ownership is a situation where a manager owns a company's shares or in other words the manager is also a shareholder of the company. Managers who are also shareholders will increase the value of the company, because by increasing the value of the company, the value of their wealth as individual shareholders will also increase. The management who is also domiciled as a shareholder will try to raise the stock price, where the stock price is influenced by the information presented by the company, one of which is profit. If reported earnings have fluctuations that will dramatically affect the level of investor confidence. If investors begin to lose their trust, the actions that investors will take are to sell their shares and this will cause the company's share price to decline which will harm other shareholders including managers.

Managers who have a lot of access to company information will have initiatives to manipulate that information if they feel that the information is detrimental to their interests (Febrianto and Erna, 2005). However, if the interests of managers and owners can be aligned, managers will not be motivated to manipulate information or do income smoothing so that the quality of accounting information and informational earnings can increase. Increased managerial ownership is expected to reduce income smoothing actions and is expected to improve financial reporting quality and profit generated. This opinion is in accordance with Pratama (2012), Midiastuty and Mahfoedz (2003) which states that managerial ownership has a negative influence on income smoothing, which means that the higher managerial ownership will minimize the practice of income smoothing. This can happen because managers think like company owners who are more concerned with the development of the company and public trust. The presence of managerial ownership will increase control within the company because managerial ownership can form harmonious and synchronous relationships as managers and company owners. With the existence of considerable managerial ownership by management and the thought of developing the company by management so that it can minimize income smoothing actions. Based on the description above, the first hypothesis developed in this study is:

H1: Managerial ownership has a negative effect on income smoothing.

The size of the company is thought to have a tendency to affect income smoothing. Larger companies have the incentive to do income smoothing compared to smaller companies because larger companies are examined and viewed more critically by various parties. Moses (1987) in Suwito and Herawaty (2005) found evidence that larger companies also have a greater incentive to do income smoothing compared to smaller companies because larger companies are subject to scrutiny (tighter supervision from the government and general public). The results of research conducted by Budiasih (2009) Yulia (2013) and Briliano et al., (2016) stated that company size has a positive effect on income smoothing practices. Based on the description above, the hypotheses developed in this study are:

H2: Company size has a positive effect on income smoothing.

Profitability is a component of the company's financial statements that aims to assess management performance. Company profitability can also be used to measure a company's ability to earn profits and know the company's effectiveness in managing its assets. In this study profitability is calculated by Return On Assets (ROA). ROA is obtained from net income divided by total assets. High profitability fluctuations have a tendency for the company to carry out income smoothing actions, especially if the company establishes a bonus compensation scheme based on the amount of profit generated. This is in accordance with the research conducted by Assih et al. (2000) in Budiasih (2009) which states that companies that have a higher ROA tend to do profit compared to lower companies because management knows the ability to earn profits in the future. making it easier to delay or speed up profits. The results of research conducted by Agustianto (2014) and Saputra (2014) state that profitability has a positive effect on income smoothing practices. Based on the description above, the third hypothesis developed in this study is:

H3: Profitability has a positive effect on income smoothing. 
A high leverage ratio indicates that most of the company's financing is financed by debt. Income smoothing practices can be triggered by a large leverage ratio. Based on the debt covenant hypothesis in positive accounting theory, that the greater the company's leverage ratio, managers tend to practice income smoothing with the aim of avoiding violations of the debt agreement. So that the higher the debt ratio, the tendency of companies to do income smoothing will also be higher. Jin and Machfoedz (1998) explain that leverage influences income smoothing based on the indication that companies do income smoothing to avoid violations of debt agreements can be seen through the company's ability to generate profits. The results of research conducted by Yulia (2013) state that leverage has a positive effect on income smoothing practices. Based on the description above, the fourth hypothesis developed in this study is:

H4: Leverage has a positive effect on income smoothing.

Management's desire to always pay low taxes is one of the factors that encourages management to practice income smoothing. Profit that is too high will result in a large tax rate that must be paid by the company, whereas low profits will show the poor performance of the company. According to Heyworth (1953) in Widodo (2011) one of the reasons for management to do income smoothing is to reduce the total tax paid by the company. Management will try to shift profits from one year to the next in order to obtain the most minimal tax payments (Tanomi, 2012). The higher the profit generated by the company, the greater the tendency of management to do income smoothing with the aim that the tax paid is lower. Kusumawati (2002) which proves that taxes affect the practice of income smoothing. The results of these studies are reinforced by research conducted by Widiawati (2016) which states that taxes have a positive influence on income smoothing practices. Based on the description above, the fifth hypothesis developed in this study is:

H5: Taxes have a positive effect on income smoothing.

\section{Research Methods}

\subsection{Operational Definition of Variables}

The dependent variable in this study is income smoothing which is measured in the form of an index that will distinguish between companies that practice income smoothing and those that do not. For the purpose of this study Eckel Index (1981) was used, as follows:

Income Smoothing index $=\frac{\mathrm{CV} \Delta \mathrm{I}}{\mathrm{CV} \Delta \mathrm{S}}$

Note:

$\mathrm{CV}$ : variable coefficient of variation, namely the standard deviation divided by the expected value.

$\Delta \mathrm{I}$ : changes in earnings in one period

$\Delta \mathrm{S}$ : changes in sales in one period

The values of $\mathrm{CV} \Delta \mathrm{I}$ dan $\mathrm{CV} \Delta \mathrm{S}$ can be calculated by the formula:

note:

$$
\mathrm{CV} \Delta \mathrm{I} \text { or } \mathrm{CV} \Delta \mathrm{S}=\sqrt{\frac{\sum(\Delta \mathrm{x}-\Delta \mathrm{x}) 2}{\mathrm{n}-1}}: \Delta \mathrm{x}
$$

$\Delta \mathrm{x}$ : change in profit (I) or sales (S) between year $\mathrm{n}$ and year $\mathrm{n}-1$

$\Delta \mathrm{x}$ : average change in profit (I) or sales (S) between year $\mathrm{n}$ and year $\mathrm{n}-1$

$\mathrm{n}$ : years observed

Criteria for companies that practice income smoothing are:

a. Companies are considered to practice income smoothing if the income smoothing index is smaller than 1.

b. The company is deemed not to do income smoothing if the income smoothing index is greater than or equal to 1 .

c. Managerial Ownership

In this study managerial ownership is calculated by dividing shares owned by management, directors and commissioners who actively participate in corporate decision making with the number of shares outstanding.

d. Company Size 
Company size is a variable that is measured by the total amount of company assets transformed in the form of natural logarithms (Suryani, 2010). Company size is calculated using the natural logarithm of total assets.

e. Profitability

In this study, company profitability is measured as Return on Assets (ROA). ROA analysis is a form of profitability ratio that is used to measure the ability of a company with the overall funds invested in assets used for the company's operations in generating profits. ROA is a ratio of net income to total assets.

f. Leverage

Leverage is measured using the debt to asset ratio. This ratio shows the amount of assets owned by companies financed by debt. This variable is measured using the ratio of total debt to total assets.

g. Tax

In this study tax is a variable measured by the total amount of corporate tax burden transformed in the form of natural logarithms. Taxes are calculated using the natural logarithm of the total tax burden.

\subsection{Samples}

The method of determining the sample used in this study is the purposive sampling method which is part of the Non Probability Sampling, namely the technique of determining the sample with certain considerations. The purpose of using the purposive sampling method is to get a sample according to the specified criteria. The criteria used are manufacturing companies listed on the IDX for the period 20152017, not conducting mergers or acquisitions, publishing financial statements that can be accessed during the study period, and using the rupiah currency in their reports. Based on these criteria obtained a total sample of 20 companies.

\subsection{Analysis Techniques}

Logistic regression analysis was used in this study because the dependent variable, income smoothing is qualitative data using dummy variables and the independent variable is a mixture of continuous (metric) and categorical (non-metric) variables (Ghozali, 2016:321). States that logistic regression is used to test whether the probability of the occurrence of the dependent variable can be predicted by the independent variable. Logistic regression analysis does not require the assumption of normality of data on the independent variables. Logistic regression analysis was carried out using the assistance of the Statistical Package for Social Science (SPSS) program.

A logistic regression model can be formed by looking at the estimated values of the parameters in the Variables in The Equation. The regression model formed based on the value of parameter estimates in the Variables in The Equation is as follows:

Note:

$$
\operatorname{Ln} \frac{P(\text { Smoothing })}{1-P(\text { Smoothing })}=\alpha+\beta \text { MOWN }+\beta \text { SIZE }+\beta \text { ROA }+\beta \text { DAR }+ \text { TAX }+e
$$

$\begin{array}{ll}\text { P } & : \text { probability income smoothing action } \\ \text { MOWN } & : \text { managerial ownership } \\ \text { SIZE } & : \text { company size } \\ \text { ROA } & : \text { profitability } \\ \text { DAR } & : \text { leverage } \\ \text { TAX } & : \text { tax } \\ \alpha & : \text { constant } \\ \beta & : \text { logit regression coefficient } \\ \text { Ln } & : \text { odds } \\ \mathrm{e} & : \text { error term }\end{array}$




\section{Result \& Discussion \\ 4.1 Logistic Regression Result}

The feasibility of the regression model was assessed using Hosmer and Lemeshow's Goodness of Fit Test. If the statistical value of Hosmer and Lemeshow's Goodness of Fit Test is greater than 0.05, it means that the model is able to predict the value of its observations or it can be said that the model is acceptable because it matches the observational data. Based on the test results (attachment), the statistical values of Hosmer and Lemeshow's Goodness of Fit Test were obtained at 9.506 with a significant value of 0.301. From these results it can be seen that the significant value is greater than 0.05 . This means that the regression model is feasible to be used in the subsequent analysis, because there is no difference between the classification predicted by the observed classification. Or it can be said that the model is able to predict the value of its observations.

This test is done by comparing the value between $-2 \log$ Likelihood (-2LL) at the beginning (Block Number $=0$ ) with the value of $-2 \log$ Likelihood $(-2 L L)$ at the end (Block Number $=1)$. The reduction in the value between the initial -2LL (initial-2LL function) and the value of -2LL in the next step (-2LL end) indicates that the model is hypothesized to be fit with the data (Ghozali, 2016: 328). The initial value of -LL is 83,111 and after five independent variables are included, the final value of -2LL decreases to 71,671 (attachment). This decrease in the value of -LL shows a good regression model or in other words the model hypothesized to fit with the data.

The coefficient of determination is used to find out how much the variability of the independent variables is able to clarify the variability of the dependent variable. The determination coefficient in logistic regression can be seen in the value of Nagelkerke R Square. Nagelkerke R Square value is 0.232 (attachment) which means the variability of the dependent variable which can be explained by the independent variable is 23.2 percent, the remaining 76.8 percent is explained by the variability of other variables outside the research model.

Classification table shows the predictive power of a regression model to predict the possibility of a company making an income smoothing action. The predictive power of the regression model to predict the probability of the occurrence of the dependent variable is expressed in percent. Classification table (attachment) shows that of the 29 observational data samples that made 17 or 58.6 percent income smoothing actions can be accurately predicted by the logistic regression model and 12 observational data not accurately predicted by the model, while from 31 observational data samples that were not make income smoothing actions 12 or 61.3 percent which can be accurately predicted by the logistic regression model, while 19 observational data are not exactly predicted by the model. So overall means the predictive power of the regression model to predict the likelihood of companies taking action on income smoothing at 60.0 percent.

A good regression model is a regression with no symptoms of a strong correlation between the independent variables. Multicollinearity testing in logistic regression using a correlation matrix between independent variables to see the magnitude of the correlation between independent variables. In the correlation matrix table shows no serious symptoms of multicollinearity between independent variables, indicated by the correlation value between independent variables below 0.8 .

Regression models formed based on the estimated value of parameters in the Variables in The Equation are as follows:

$$
\begin{aligned}
& \operatorname{Ln} \frac{P(\text { Smoothing })}{1-\mathrm{P}(\text { Smoothing })} \\
& \quad=-5,786+0,054 \text { MOWN }+0,256 \text { SIZE }-0,042 \text { ROA + 0,021 DAR }-0,109 \text { TAX }
\end{aligned}
$$

\subsection{Discussion}

Based on the test results show managerial ownership variables have a positive regression coefficient of 0.054 with a significance level of 0.088 which is greater than $\alpha(0.05)$. This means that managerial ownership has no effect on income smoothing. The size of managerial ownership owned by management does not affect the occurrence of income smoothing actions. The average manufacturing company that is the sample in this study has a very low number of managerial ownership, namely with an average managerial ownership of 9.0523 . Thus the results can not be used to show that managerial ownership can influence income smoothing actions by management. This indicates that managerial ownership does not necessarily indicate management incentives to practice income smoothing. The 
results of this study are in accordance with the results of research conducted by Noviana and Yuyetta (2011), Pratiwi and Handayani (2014) which state managerial ownership does not affect the practice of income smoothing. Other results found by Widiatmaja (2010) and Widiawati (2016) found results that managerial ownership had an effect on income smoothing practices.

Firm size has a positive regression coefficient of 0.256 with a significance level of 0.574 which is greater than $\alpha(0.05)$. Based on this, it can be concluded that the variable size of the company has no effect on income smoothing. Total assets describe the value of assets or assets owned by a company. The greater the total value of the company's assets reflects that the company has assets that are increasingly high in value, so that it can be said the size of the company can be seen from the size of the total value of assets of a company. The total assets owned by the company, cannot ensure a company will earn a profit in carrying out its business activities, this indicates that the size of the company does not affect the keiginan of the company to practice income smoothing. The results of this study are in accordance with the results of research conducted by Dewi (2010) and Prasetya (2013) stating that firm size has no effect on income smoothing, while Rahmawati (2012) and Narayani (2017) conclude that firm size affects income smoothing.

Profitability has a negative regression coefficient of -0.042 with a significance level of 0.555 which is greater than $\alpha(0.05)$. This means that profitability has no effect on income smoothing. Management that is motivated to maintain a position or get a bonus does not take into account the size of the profits generated by the company, so management is not motivated to practice income smoothing through profitability variables. The profitability produced by the company in the period of this study did not fluctuate too much, namely the average profitability of 6.8982 , so it did not affect the company to practice income smoothing. The results of this study are in accordance with the results of research conducted by Wulandari (2013) and Narayani (2017) which state that profitability does not affect the income smoothing practice. Other results found by Cendy (2013) and Saputra (2014) found that profitability had an effect on the practice of income smoothing. The leverage variable has a positive regression coefficient of 0.021 with a significance level of 0.030 that is smaller than $\alpha(0.05)$. This means that leverage has a positive effect on income smoothing. Debt covenant hypothesis in positive accounting theory, which states that the greater the leverage ratio of the company, the management will tend to practice income smoothing with the aim of avoiding violations of the debt agreement. So that the higher the debt ratio, the tendency of companies to do income smoothing will also be higher. The results of this study are in accordance with the results of research conducted by Yulia (2013) which states that leverage has a positive effect on income smoothing practices. But it is not consistent with the research conducted by Widaryanti (2009) and Setyaningtyas (2014) who found that leverage did not affect the income smoothing practice.

The next variable is Tax, has a negative regression coefficient of -0.109 with a significance level of 0.791 which is greater than $\alpha(0.05)$. This means that taxes have no effect on income smoothing. The obligation of management to pay taxes to the government, whether in large or small amounts, and the amount of tax imposition rates set by the government will not affect the company to carry out income smoothing actions. Besides the strictness of the tax regulations issued by the government does not affect the company to practice income smoothing, this is because in this study the amount of tax burden imposed on most companies is also not too fluctuating. The results of this study are in accordance with the results of a study conducted by Pratiwi and Handayani (2014) stating that taxes do not affect income smoothing, while Widiawati (2016) concludes that taxes affect income smoothing.

\section{Conclusion}

The purpose of this study is to examine and obtain empirical evidence the influence of managerial ownership, company size, profitability, leverage, and tax on income smoothing. Sample selection using purposive sampling technique and obtained as many as 20 manufacturing companies that meet the sample criteria. The data analysis technique in this study uses logistic regression analysis. Based on the results of the analysis it can be concluded that the leverage proxied by DAR has a positive effect on income smoothing. While managerial ownership, company size, profitability, and taxes have no effect on income smoothing.

This study only uses five variables, namely managerial ownership, company size, profitability, leverage and tax in knowing the relationship to income smoothing. Future studies can add other variables 
that theoretically have a relationship to income smoothing such as Public Ownership, Institutional Ownership, Dividend Payout Ratio, Current Ratio, Industrial Sector, and Type of Business. This study uses the Eckel model (1981) to determine companies that do income smoothing with companies that do not do income smoothing. It is recommended that further research can use other models such as Michelson (1995) or Moses (1987), with the aim to find out whether using other models will get the same or different results.

\section{References}

[1] Agustianto, Rio Nur. (2014). Analysis of influential factors on profit flattening (empirical study on manufacturing companies listed on the Indonesia Stock Exchange in 2011-2013). Thesis. Economics and Business Faculty. Diponegoro University.

[2] Atarmawan, Rita. D.J. (2011). Analysis of the effect of company size, profitability, and managerial ownership on profit leveling practices in manufacturing companies listed on the Indonesia Stock Exchange. Advantage Economics Journal. Vol. 2. No. 2.

[3] Brilliano, Arif Pradhana, Khairun Nisa and Son of God Krishna. 2016. Effects of the audit committee, company size, taxes, managerial ownership and audit quality on profit flattening (empirical study on manufacturing companies listed on the Indonesia Stock Exchange in 2011-2015). E-Journal Economics and Business. Telkom University.

[4] Baridwan, Zaki. 2008. Intermediate accounting. Eighth edition. Yogyakarta: BPFE

[5] Budiasih. I.G.A.N. 2009. Factors affecting profit smoothing practices. Akuntansi dan Bisnis Journal. Faculty of Economics. Udayana University.

[6] Cendy, Yasintha Pradnyamitha. 2013. Effect of cash holding, profitability, and company value on income smoothing (empirical study on companies listed on the Indonesia Stock Exchange in 2009 2011). Thesis. Faculty of Economics and Business. Diponegoro University.

[7] Dewi, Diastiti Okkarisma. 2010. Effect of business type, company size, and financial leverage on profit smoothing measures on companies listed on the indonesia stock exchange (empirical study on the Indonesia Stock Exchange). Thesis. Faculty of Economics. Diponegoro University.

[8] Dewi, Made Yustiari and I Ketut Sujana. 2014. Effect of company size and profitability on profit leveling practice with industrial types as moderating variables in the Indonesia Stock Exchange. Akuntansi dan Bisnis Journal. Faculty of Economics. Udayana University.

[9] Dwimulyani, Susi and Yoga Abraham. 2006. Analysis of income smoothing, factors affecting and relating to the performance of shares of public companies in Indonesia. Informasi, Perpajakan, Akuntansi dan Keuangan Publik Journal. Faculty of Economics. Trisakti University.

[10] Ghozali, Imam. 2016. Multivariate analysis application with IBM SPSS 23 program. 8th Edition. Semarang: Diponegoro University.

[11] Habib, A., and Jiang, H. (2012). Managerial ownership-induced income smoothing ans information asymmetry. Pacific Accounting Review, 24(2), 211-232.

[12] Hastuti, Rini Tri. 2017. Factors affecting income smoothing in manufacturing companies listed on the Indonesia Stock Exchange 2013-2015. E-Journal. Faculty of Economics. Tarumanegara University.

[13] Jensen, M.C. and Meckling, W.H. 1976. Theory of the firm: managerial behavior, agency cost, and ownership structure. Journal of Financial Economics 3.

[14] Juniarti and Corolina. 2005. Analysis of the influential factors on income smoothing on companies that go public. Akuntansi dan Keuangan Journal. Faculty of Economics. Petra Christian University.

[15] Kasmir. 2012. Financial statemnet analysis. Fifth print. Jakarta: PT Raja Grafindo Persada.

[16] Koh, P. (2005). Institutional ownership and income smoothing: Australian evidence. Accounting Research Journal, 18(2), 93-110.

[17] Midiastuty, Pranata and Mas'ud Marchfoedz. 2003. Analysis of relations between the corporate governace mechanism and indication of profit management. Accounting National Seminar VI, Surabaya, October 16-17, 2003 page: 176-186.

[18] Noviana, Sindi Retno and Etna Nur Afri Yuyetta. 2011. analysis of factors affecting income smoothing. E-Journal. Faculty of Economics. Diponegoro University.

[19] Prabayanti, Ni Luh Putu Arik and Gerianta Wirawan Yasa. 2009. income smoothing and analysis of affecting factors (study of manufacturing companies listed on the Indonesia Stock Exchange). E-Journal. Udayana University. 
[20] Pratama, Dika Fajar. 2012. effect of profitability, financial risk, corporate value, ownership structure and devidend payout ratio on income smoothing. Akuntansi dan Investasi Journal. Vol. 4, No.1.

[21] Prasetya, Harris. 2013. Effects of company size, profitability, financial leverage, kap classification and liquidity on income smoothing. Thesis. Faculty of Economics. Diponegoro University.

[22] Pratiwi, Herlinda and Bestari Dwi Handayani. 2014. effects of profitability, managerial ownership and tax on income smoothing. Journal of Analisis Akuntansi. Faculty of Economics. Semarang State University.

[23] Rahmawati, Dina. 2012. Analysis of the influential factors against the practice of profit smoothing (study on manufacturing companies listed on the Stock Exchange in 2007 - 2010). Thesis. Faculty of Economics and Business. Diponegoro University.

[24] Rehobot, Tanomi. 2012. Effects of management compensation, debt and tax agreements on profit management in manufacturing companies in Indonesia. Journal of Ilmiah Akuntansi. Vol. 1, No. 3, May 2012.

[25] Saputra, Okky Harra Novian. 2014. Factors affecting profit equity in companies on the indonesia stock exchange. E-Journal. Dian Nuswantoro University Semarang.

[26] Setiawan, Andreas Dwi. 2011. Analysis of factors affecting income smoothing in financial companies listed on the Indonesia Stock Exchange. Thesis. Faculty of Economics. University of Jember.

[27] Setyaningtyas, Ina. 2014. Analysis of factors affecting income smoothing. Thesis. Faculty of Economics and Business. Diponegoro University.

[28] Sugiyono, 2017. Quantitative, qualitative research methodology and $R \& B$.. Bandung. Alfabeta.

[29] Wahyuningsih, Dwi Retno. 2007. practice relations earnings management with market reactions for announcement of information on profit of manufacturing companies in the Jakarta Stock Exchange. Thesis. Diponogoro University.

[30] Widaryanti. 2009. Analysis of profit flattening and factors affecting manufacturing companies on the indonesia stock exchange. Fokus Ekonomi. Vol. 4 No. December 2, 2009: 60 - 77.

[31] Widiawati, Ani. 2016. Analysis of the effects of profitability factors, managerial ownership, taxes, financial leverage and company size on income smoothing in property and real estate companies listed on the Indonesia Stock Exchange in 2010-2014. Thesis. Economics and Business Faculty. University of Lampung.

[32] Wulandari. 2013. Analysis of factors affecting income smoothing and its impact on company values in manufacturing companies listed on the indonesia stock exchange period 2008-2011. Thesis. Faculty of Economics and Business. Diponegoro University.

[33] Yang, C., Leing Tan, B., \& Ding, X. (2012). Corporate governance and income smoothing in China. Journal of Financial Reporting and Accounting, 10(2), 120-139.

[34] Yulia, Mona. 2013. Effect of company size, profitability, financial leverage, and value of shares on income smoothing on manufacturing, finance and mining companies listed on the Indonesia Stock Exchange. Thesis. Faculty of Economics. Padang State University.

[35] Zen, Sri Daryanti and Merry Herman. 2007. Effect of stock prices, company age, and company profitability ratio on profit leveling measures conducted by banking companies listed on the Jakarta Stock Exchange. E-Journal. Faculty of Economics. Andalas State University 